\title{
東京都内河川水中の界面活性剂の濃度分布と挙動
}

\section{The distribution and fate of major surfactants in some river waters in Tokyo}

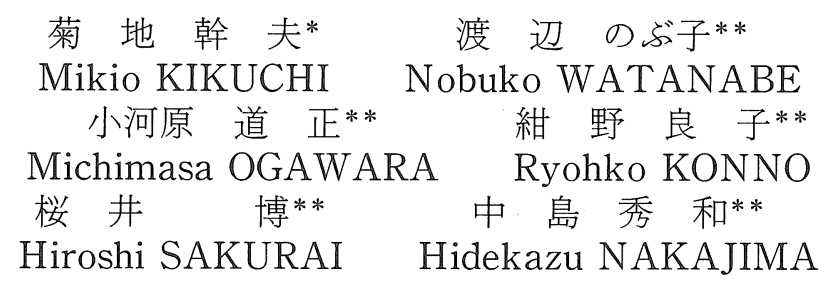

\begin{abstract}
The distribution and fate of major surfactants in some river waters in Tokyo were examined. The anionic surfactant concentration was high in the branch streams and low in the main streams. In its seasonal variations, it is high in winter and low in summer and fall. The anionic surfactant concentrations were closely connected with the methylene blue active substance concentrations. The composition of anionic surfactant is as follows : linear alkylbenzenesulfonates (LAS) $79.8 \pm 17.7 \%$ (mean \pm SD, $\mathrm{n}=8)$ and sulfates $10.3 \pm 6.5 \%(\mathrm{n}=9)$ in summer; LAS $81.9 \pm 6.1 \%(\mathrm{n}=10), \alpha$-olefin sulfonates(AOS) 2 . $6 \pm 0.6 \%(n=4)$, and sulfates $7.9 \pm 6.4 \%(n=10)$ in fall; LAS $72.7 \pm 7.2 \%(n=13)$, AOS $2.5 \pm 1.1 \%(n=4)$, and sulfates $23.2 \pm 6.0 \%(n=13)$ in winter. The nonionic surfactant concentration is a small minority comprising only $10-11 \%$ of the anionic surfactant concentration in fall and winter. The composition of anionic surfactant or LAS composition in the river waters is somewhat different from that in the household synthetic detergent on market and depend on the season. This was cased by the adsorption, the deposition and the biodegradation in the river and the sewage disposal.
\end{abstract}

Key words : fate, surfactant, linear alkylbenzenesulfonates, detergent, biodegradation

\section{1.はじめに}

合成洗剂を含む生活排水の一部は，下水処理施設等 で処理されないま公共用水域に流入する。合成洗剂 の主要成分である界面活性剂は, その種類によって魚 等の水生生物に与劣る影響, 実験室での生分解試験結 果や下水処理場での分解特性などが大きく異なること が分かってきた1) 4)。したがって，ある水域に流入した 界面活性剤がそこに生息する水生生物にどの程度の影 響を与えるかを評価するためには，その水域の全界面 活性剤濃度とともに個々の界面活性剂の濃度を把握す ることが必要となる。また，これらの界面活性剤の水 域への流入量と水域での挙動等を明らかにする必要が ある。
このような視点から，本論文は，

(1)メチレンブルー法 (JIS K0102-1981 30.1) 5) で全陰イ

オン界面活性剂濃度を的確に把握できるか,

(2)河川水中からはどのような種類の界面活性剤が検出 されるか,

(3)これらの界面活性剂はどのような挙動を示すか, を明らかにすることを目的とした。

\section{2. 実験方法}

\section{1 調査地点おょび試料}

調查地点をFig. 1 亿示した。水域別, 生活環境の保 全に関する環境基準の類型別に都内 10 河川 13 地点を選 定し, 夏季 (1983年 8 月 $2 \sim 3$ 日), 秋季 (1983年11月

* 東京都環境科学研究所 $=136$ 江東区新砂1-7-5, The Tokyo Metropolitan Research Institute for Environmental Protection, Shinsuna 1, Koto-ku, Tokyo 136, Japan

** 東京都環境保全局 $=100$ 千代田区有楽町1-7-1, Environmental Protection Bureau, Tokyo Metropolitan Government, Yuraku-cho 1, Chiyoda-ku, Tokyo 100, Japan 


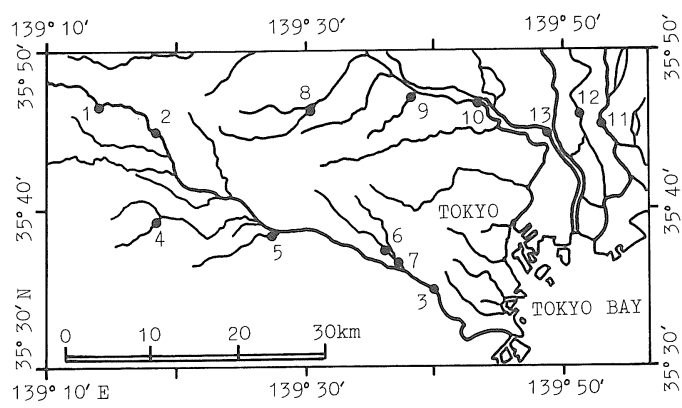

Fig. 1 Sampling stations in Tokyo.

Notes:

\begin{tabular}{|c|c|c|}
\hline No. & Station & $\begin{array}{l}\text { The categories of } \\
\text { water quality standard }\end{array}$ \\
\hline 1 & $\begin{array}{l}\text { The Tama River } \\
\text { (the Wada Bridge) }\end{array}$ & AA \\
\hline 2 & $\begin{array}{l}\text { The Tama River } \\
\text { (the Hamura Sluice) }\end{array}$ & A \\
\hline 3 & $\begin{array}{l}\text { The Tama River } \\
\text { (the Den'enchofuSluice) }\end{array}$ & $\mathrm{C}$ \\
\hline 4 & The Minami-asa River & B \\
\hline 5 & The Ooguri River & $\mathrm{C}$ \\
\hline 6 & $\begin{array}{l}\text { The No River } \\
\text { (the Tenjinmori Bridge) }\end{array}$ & $\mathrm{D}$ \\
\hline 7 & $\begin{array}{l}\text { The No River } \\
\text { (the junction of the Tama River) }\end{array}$ & $\mathrm{D}$ \\
\hline 8 & The Karabori River & $\mathrm{E}$ \\
\hline 9 & The Shirako River & $\mathrm{E}$ \\
\hline 10 & The Shingashi River & $\mathrm{E}$ \\
\hline 11 & The Edo River & A \\
\hline 12 & The Naka River & $\mathrm{D}$ \\
\hline 13 & The Ara River & $\mathrm{D}$ \\
\hline
\end{tabular}

$8 \sim 9$ 日) 及び冬季（1984年 2 月 7 ～日）に各一回 ずつ調査した。河川の流心で表層水を採取し，検水と した。ただし， $\alpha$ ーオレフィンスルホン酸ナトリウム(以 下 AOS と略す) と非イオン界面活性剂は, 河川水中で の濃度が低いことを考慮して，多くの水質測定データ のある多摩川田園調布堰上之污濁の進んでいる 4 地点 （南浅川, 野川天神森橋, 空堀川, 白子川)の夕で11月 と 2 月の検水について測定した。

\section{2 試 薬}

直鎖アルキルベンゼンスルホン酸ナトリウム（以下 LAS と略す。花王株式会社, 組成 $\mathrm{C}_{10}, 3-5 \mathrm{ph}$ (アル キル基の炭素数が10で, 3 - 5 の位置にスルホフェニル 基をもつ異性体） 8 モル\%，2 $\mathrm{ph} 2 \%$ ； $\mathrm{C}_{11} ， 3-6 \mathrm{ph}$ $28 \%, 2$ ph $7 \% ; \mathrm{C}_{12}, 3-6$ ph $25 \%, 2$ ph $6 \%$; $\mathrm{C}_{13}, 3-7 \mathrm{ph} 19 \%, 2$ ph $3 \% ; \mathrm{C}_{14} 2 \%$, 平均分子量
344)。AOS( $\mathrm{A}$ 社，親油基組成 $\mathrm{C}_{16} 58 \%, \mathrm{C}_{18} 42 \%$ ， ア ルケニル基とヒドロキシル基の比 $75.3: 24.7$, 平均分 子量350.7)。硫酸アルキルポリ（オキシエチレン）=ナ トリウム(以下 $\mathrm{AES}$ と略す。 $\mathrm{B}$ 社, アルキル基組成 $\mathrm{C}_{12}$ 約 $20 \%, \mathrm{C}_{13}$ 約 $30 \%, \mathrm{C}_{14}$ 約 $30 \%, \mathrm{C}_{15}$ 約 $20 \%$, 直鎖率 $78 \pm 2 \%$, 平均エチンンオキシド付加モル数 3 )。硫酸 ドデシルニナトリウム（関東化学株式会社）。ドデシル ニヘプタ (オキシェチレン) =エーテル（日光ケミカル ズ株式会社)。Bond Elut $\mathrm{C}_{18}$ (Analytichem International, Inc., Calif., 500mg 吸着体)。アセトニトリル (関東化学株式会社, 無蛍光溶媒)。その他の試薬は特 級を用いた。

\section{3 分析方法}

前処理：文献6を参考にして，検水を実験室に持ち 帰った後直ちに以下のように前処理した。検水（メチ レンブルー活性物質（以下 MBAS と略す）として約 $250 \mu \mathrm{g}$ を含む)をがラス繊維ろ紙GF/C (Whatman Ltd, U.K.) でろ過し， 万紙上の残査を少量（検水量の $2 \%$ 以下）のメタノールで洗浄し，洗浄液をろ液に合わせ た。得られた水溶液を 4 〜 分割し，あらかじめ数 $\mathrm{ml}$ のメタノールと数 $\mathrm{ml}$ の蒸留水で洗浄した Bond Elut $\mathrm{C}_{18}$ に流速約 $30 \mathrm{ml} /$ 分（減圧度 $15 \mathrm{inchHg}$ ) で通した。水 溶液を通し終えた後, Bond Elut $\mathrm{C}_{18}$ を数 $\mathrm{ml}$ の蒸留水 で一度, $3 \mathrm{ml}$ の $30 \%$ メノールで二度洗浄した。 （30\%×タノールによる洗浄は，着色物質を除くため に行った。ただし，8月と11月の検水の分析とAOS の 分析では， $30 \%$ メタノールによる洗浄は行っていな い。） $5 \mathrm{ml}$ のメタノールで Bond Elut $\mathrm{C}_{18}$ に吸着され た陰イオン界面活性剂を溶離させた。溶離液を合わせ て定容にし, 全陰イオン界面活性剂分析用, スルホネー 卜型陰イオン界面活性剂（以下スルホネートと略す） 分析用, LAS 分析用, 予備用の検体に分割し, 分析時 まで冷暗所に保存した。AOS 分析には, MBAS として $3 \sim 11 \mathrm{mg}$ を含む検水を同様に処理して検体を調製し た。

全陰イオン界面活性剂濃度の定量：前処理済の検体を メチレンブルー法で分析した5)。

スルホネート濃度の定量: 前処理済の検体をJIS K0102-1981 30.1 備考 3 により加水分解した後, メチ レンブルー法で分析した ${ }^{5)}$ 。(加水分解による残存率 は, LAS 97\%, AOS 87\%, AES 0 \%である。) サルフェート型陰イオン界面活性剤（以下サルフェー 卜之略す）濃度の算出：全陰イオン界面活性剤濃度か らスルホネート濃度を差し引いて求めた ${ }^{5)}$ 。

LAS 濃度の定量 : 前処理済の検体に加温下で窒素が スを吹さつけて乾固させた後, メタノール 0.5 なた 1 $\mathrm{ml}$ を加えて溶かし，高速液体クロマトグラフィー（以 
下 HPLC と略す）で分析した ${ }^{6)}$ 。

HPLC の装置及び運転条件：ポンプ（日本分光工業株 式会社, トライローター), 検出器 (日本分光工業株式 会社, FP-550型分光虽光光度計, Ex221nm, Em284 $\mathrm{nm}$ ), カラム（東ソー株式会社, TSK-ゲル ODS-120 $\mathrm{T}, 0.46 \phi \times 25 \mathrm{~cm})$, カラム温度 $\left(40^{\circ} \mathrm{C}\right)$, 溶離液 $(0.1 \mathrm{M}$ $\left.-\mathrm{NaClO}_{4} \quad \mathrm{CH}_{3} \mathrm{CN} / \mathrm{H}_{2} \mathrm{O}(65 / 35)\right)$, 流速 $0.6 \mathrm{ml} /$ 分。 $\mathrm{AOS}$ 濃度の定量：前処理済の検体を濃縮乾固し， 0.5 $\mathrm{N}-\mathrm{H}_{2} \mathrm{SO}_{4}$ を加光て加水分解し, $3 \mathrm{~N}-\mathrm{NaOH}$ で中和 し, 石油ェーテルで洗浄した。水層から AOSをメチレ ンブルー錯体としてクロロホルムで抽出し，5\%プラ チナ炭素を触媒として水素添加し，イオン交換樹脂で 処理した後, 塩化チオニルでスルホニルニクロリドとし た。これを四塩化炭素溶液とし，ガスクロマトグラ フィー/マススペクトロメトリー（以下 $\mathrm{GC} / \mathrm{MS}$ と略 す) で定量した。

GC/MS の装置扔よび運転条件：本体（株式会社島津 製作所，LKB-9000型ガスクロマトグラフ質量分析 計), カラム ( $1 \% \mathrm{SE}-30$ Gas Chrom Q 60-80メッ シュ, パイレックス $3 \mathrm{~mm} \times 1 \mathrm{~m})$, カラム温度 $\left(180^{\circ} \mathrm{C}\right.$ 恒温または $150-200^{\circ} \mathrm{C}$ を $5^{\circ} \mathrm{C} /$ 分昇温), 注入口温度 $\left(225^{\circ} \mathrm{C}\right)$, セパレータ温度 $\left(230^{\circ} \mathrm{C}\right)$, イオン源温度 $\left(250^{\circ}\right.$ C), キャリアガス(ヘリウム $30 \mathrm{ml} /$ 分)，イオン化電压 $(20 \mathrm{eV})$, 加速電圧 $(3.5 \mathrm{kV})$

その他の項目：MBAS, 非イオン界面活性剤, 生物化 学的酸素要求量 (以下 $\mathrm{BOD}$ と略す) 之塩化物イオンに ついては，前記の前処理は行わずに JIS K0102-19815) で分析した。

全陰イオン界面活性剂，スルホネート，サルフェー ト，LAS，AOS とMBAS の濃度は。いずれも硫酸ド デシル=ナトリウムに換算して表示した。また各界面活 性剂の定量下限值は，全陰イオン界面活性剤，スルホ ネートとサルフェートでは $1 \mu \mathrm{g}, \mathrm{LAS}$ では $0.05 \mu \mathrm{g}$, AOS では $0.016 \mathrm{mg} / 1, \mathrm{MBAS}$ では $0.02 \mathrm{mg} / 1$, 非イオン 界面活性剂では0.1mg/1である。

\section{3. 結果}

\section{1 分析の前処理条件の検討}

陰イオン界面活性剤 (MBAS として24〜31 $\mu \mathrm{g}$ ) を蒸 留水 11 または河川水 11 亿添加し, Bond Elut $\mathrm{C}_{18}$ に よる回収率を検討し，Table 1 に示した。LAS，AOS や AES は蒸留水または河川水中から好収率で回収で きた。また, Bond Elut $\mathrm{C}_{18}$ 一本当りにどの程度の負荷 がかけられるか検討し，Table 2 に示した。河川水を対 象とした場合, MBAS として $440 \mu \mathrm{g}$ （検水量として 4 1）まで使用可能であることを確認した。そこで今回の 調査では，Bond Elut $\mathrm{C}_{18}$ 一本当りの負荷量を MBAS
Table 1 Recovery of the major surfactants by use of Bond Elut $\mathrm{C}_{18}$

\begin{tabular}{|c|c|c|c|c|}
\hline \multicolumn{4}{|c|}{ Sample } & \multirow{3}{*}{$\begin{array}{l}\text { Recovery of the added } \\
\text { surfactant, \% }\end{array}$} \\
\hline \multirow{2}{*}{ Water } & \multicolumn{3}{|c|}{ Surfactant ${ }^{*}, \mu \mathrm{g} / 1$} & \\
\hline & Present & Added & Found & \\
\hline \multirow[t]{5}{*}{ Distilled water, 11} & 0 & LAS 31.3 & 30.2 & 96.5 \\
\hline & & & 31.5 & 101 \\
\hline & & & 31.6 & 101 \\
\hline & & & 30.9 & 98.7 \\
\hline & & & 30.3 & 96.8 \\
\hline \multirow[t]{2}{*}{ River water, 11} & 23.1 & LAS 31.3 & 55.5 & 104 \\
\hline & & & 51.1 & 89.5 \\
\hline \multirow[t]{2}{*}{ River water, 11} & 23.1 & AOS 24.1 & 46.1 & 95.4 \\
\hline & & & 45.2 & 91.7 \\
\hline \multirow[t]{3}{*}{ River water, 11} & 23.1 & AES 26.9 & 50.8 & 103 \\
\hline & & & 49.2 & 97.0 \\
\hline & & & 49.9 & 99.6 \\
\hline
\end{tabular}

* Determined as MBAS by methylene blue method

Table 2 The effect of sample volume of the river water on the observed LAS concentration

\begin{tabular}{|c|c|}
\hline $\begin{array}{c}\text { Sample volume of the river water } \\
1\end{array}$ & $\begin{array}{c}\text { Observed LAS concentration }{ }^{* 2} \\
\mu \mathrm{g} / 1\end{array}$ \\
\hline 0.5 & 109 \\
1.0 & 106 \\
2.0 & 118 \\
4.0 & 107 \\
\hline
\end{tabular}

* 1 The river water was treated by a Bond Elut $\mathrm{C}_{18}$ * 2 Determined by HPLC

\section{として約 $50 \mu \mathrm{g}$ とした。}

\section{2 夏季の界面活性剤濃度}

都内 9 河川11地点での界面活性剂濃度を Fig. 2 に 示す。採水の前日に小雨が降ったが，採水当日は晴ま たは黄であった。河川流量への降雨の影響は江戸川を 除いて汪とんどなかった。江戸川は，7 月中旬以降に 水源地集中豪雨があり，金町取水点では水量が多 かった。水温は多摩川の和田橋が $16.9^{\circ} \mathrm{C}$ と低かった

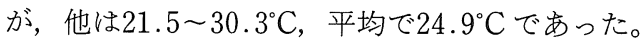

MBAS 9 河川 9 地点で検出され, 最大值は, 空堀 川の $2.35 \mathrm{mg} / 1$ であり, 一方, 多摩川上流部の和田橋々 羽村堰，江戸川（金町取水点）では定量下限值未満で あった。

LAS は全地点で検出され, 最大值は空堀川の 1.78 mg/lであり, MBAS が定量下限值未満であった多摩 川の和田橋, 羽村堰と江戸川では $0.003 \sim 0.004 \mathrm{mg} / 1$ で あった。

全陰イオン界面活性剂は MBAS の73 100\%, 平均 で $81 \%$ (検体数 $\mathrm{n}=9$ ), LAS は MBAS の36 83\%, 

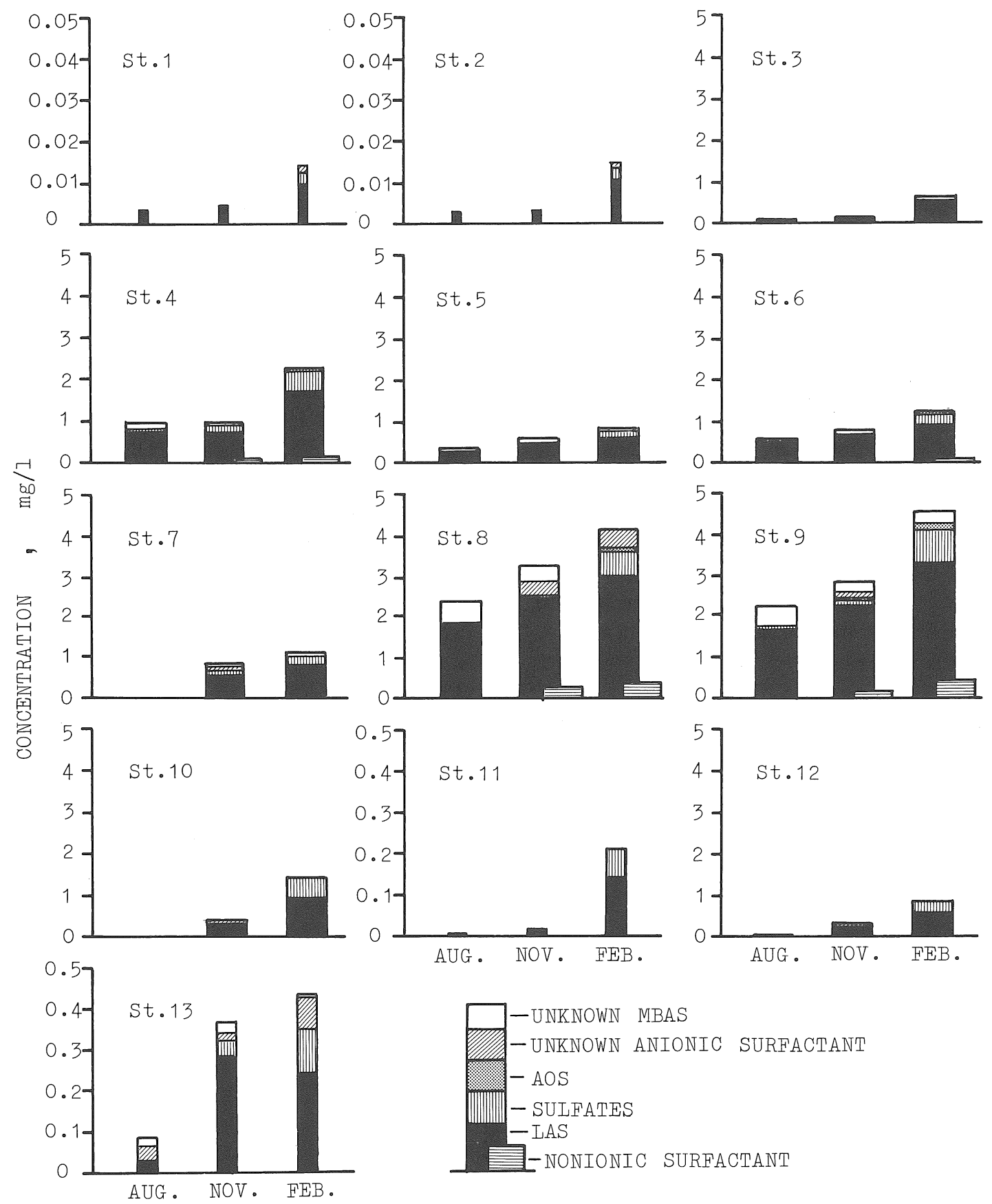

Fig.2 Seasonal variations of the major surfactant concentrations in the river waters of each stations.

At St. 7 or 10, the surfactant concentration was not measured or not illustrated at August, 1983, respectively. At St.1,2 and 11, only LAS concentration was illustrated at August and November, 1983.

AOS or nonionic surfactant was only measured at St. 3,4,6,8 and 9 on November, 1983 and February, 1984. In the other case AOS was included in unknown anionic surfactant. 
平均で $65 \%(\mathrm{n}=8)$, サルフェートはMBAS の 1 $\sim 17 \%$, 平均で $8 \%(\mathrm{n}=9)$ を占めていた。多摩川の 和田橋, 羽村堰と江戸川では, 全陰イオン界面活性剂 濃度とサルフェート濃度は測定していない。また，夏 季の調査ではAOS 濃度と非イオン界面活性剂濃度を 測定していない。

\section{3 秋季の界面活性剤濃度}

都内10河川13地点での界面活性剂濃度を同じく Fig. 2 亿示した。採水の前日 2 日間は雨で, 採水当日は 晴または晴後所により小雨であった。水温は $12.8 \sim 17.8^{\circ} \mathrm{C}$ 平均 $15.0^{\circ} \mathrm{C}$ であった。

MBAS は, 多摩川の和田橋と羽村堰を除いた10河川 11 地点で検出され, 最大值は空堀川の $3.31 \mathrm{mg} / 1$ であっ た。

LAS は全地点で検出され，最大值は $2.37 \mathrm{mg} / 1$ (空堀 川), 最小値は $0.003 \mathrm{mg} / 1$ (多摩川羽村堰) であった。

AOS は測定した 5 地点中多摩川田園調布堰上を除 く 4 地点で検出され, その検出範囲は 0.016 (南浅川, 野川天神森橋） 0.089mg/1 (空堀川) であった。

非イオン界面活性剂は測定した 5 地点中多摩川田園 調布堰上と野川天神森橋を除く 3 地点で検出され，そ の検出範囲は 0.14 (南浅川) $\sim 0.24 \mathrm{mg} / 1$ (空堀川) で あった。

全陰イオン界面活性剂は MBAS の78 94\%，平均 で88\%（ $\mathrm{n}=10)$, LAS は MBAS の 63 79\%, 平均で $73 \%(n=11), A O S$ はBAS の $2 \sim 3 \%$, 平均で $2 \%$ $(\mathrm{n}=4)$, サルフェートはMBAS の $1 \sim 18 \%$, 平均で $7 \%(\mathrm{n}=10)$ を占めていた。

非イオン界面活性剂は, MBAS の $6 \sim 15 \%$, 平均で $9 \%(\mathrm{n}=3)$ の濃度であった。多摩川和田橋, 羽村堰と 江戸川では, 全陰イオン界面活性剤濃度とサルフェー
ト濃度は測定していない。

\section{4 冬季の界面活性剤濃度}

都内10河川13地点での界面活性剂濃度を同じく Fig. 2 亿示した。採水日より前は晴天が続いていた。水 温は2.2 9. $0^{\circ} \mathrm{C}$ 平均で $4.7^{\circ} \mathrm{C}$ であった。

MBAS は多摩川の和田橋と羽村堰を除いた10河川 11地点で検出され, 最大值は白子川で $4.29 \mathrm{mg} / 1$ であっ た。

LAS は全地点で検出され, 最大值は白子川の 3.30 $\mathrm{mg} / \mathrm{l}$ であり, MBAS が定量下限值未満であった多摩 川の和田橋と羽村堰では $0.01 \mathrm{mg} / 1$ であった。な执, 多 摩川の和田橋, 羽村堰と江戸川の LAS 濃度は, 夏季, 秋季より数倍から数十倍も高かった。AOS は 5 地点中 多摩川田園調布堰上を除く 4 地点で検出され，濃度は 0.024 (南浅川) 0.147mg/1（白子川）であった。

非イオン界面活性剤は，測定した 5 地点中多摩川田 園調布堰上を除く 4 地点で検出され，その検出範囲は 0.11 (野川天神森橋) 0.43mg/1 (白子川)であった。

全陰イオン界面活性剂は MBAS の 90 ～100\%，平均 で97\% ( $\mathrm{n}=11)$, LAS は MBAS の56 81\%, 平均で $73 \%(\mathrm{n}=11), \mathrm{AOS}$ は MBAS の 1 ～3\%, 平均で $2 \%$ $(\mathrm{n}=4)$ ，サルフェートはMBAS の $12 \sim 35 \%$, 平均で 24\%（n=11）を占めていた。

非イオン界面活性剂は MBAS 濃度の 8 ～10\%，平 均で $9 \%(n=4)$ の濃度であった。

\section{5 界面活性剤の濃度分布}

界面活性剂による污染を生活環境の保全に関する環 境基準の類型別にみると，いずれの界面活性剤につい ても，E 類型で高く，AA，A 類型で低い傾向がある。 一つの水系を多摩川を例としてみると，人口密度が低 い本川の上流部では濃度が低く，人口密度の高い支川

Table 3 Characteristics of LAS in the river waters.

\begin{tabular}{|c|l|c|c|}
\hline \multirow{2}{*}{ Day } & \multirow{2}{*}{$\begin{array}{c}\text { Sampling } \\
\text { station }\end{array}$} & \multicolumn{2}{|c|}{ Characteristics of LAS } \\
\cline { 3 - 4 } & Carbon number of alkyl chain & $2 \mathrm{ph}, \mathrm{mol} \%$ \\
\hline \multirow{3}{*}{ Aug.1983 } & Upper or branch stream & $11.52 \pm 0.08(\mathrm{n}=7)$ & $14.6 \pm 3.1(\mathrm{n}=7)$ \\
& Mid-or down-stream & $11.38 \pm 0.26(\mathrm{n}=4)$ & $6.1 \pm 3.8(\mathrm{n}=4)$ \\
& Total & $11.46 \pm 0.17(\mathrm{n}=11)$ & $11.5 \pm 5.3(\mathrm{n}=11)$ \\
\hline \multirow{3}{*}{ Nov.1983 } & Upper or branch stream & $11.56 \pm 0.04(\mathrm{n}=9)$ & $14.7 \pm 2.1(\mathrm{n}=9)$ \\
& Mid-or down-stream & $11.42 \pm 0.18(\mathrm{n}=4)$ & $10.9 \pm 2.1(\mathrm{n}=4)$ \\
& Total & $11.52 \pm 0.12(\mathrm{n}=13)$ & $13.5 \pm 2.7(\mathrm{n}=13)$ \\
\hline \multirow{3}{*}{ Feb.1984 } & Upper or branch stream & $11.61 \pm 0.06(\mathrm{n}=9)$ & $16.7 \pm 1.7(\mathrm{n}=9)$ \\
& Mid-or down-stream & $11.45 \pm 0.15(\mathrm{n}=4)$ & $11.9 \pm 5.4(\mathrm{n}=4)$ \\
& Total & $11.56 \pm 0.12(\mathrm{n}=13)$ & $15.3 \pm 3.8(\mathrm{n}=13)$ \\
\hline
\end{tabular}

Upper or branch stream: St. $1,2,4,5,6,7,8,9$, and10.

Mid- or downstream: St.3,11,12, and13.

2ph represents LAS isomers containing 2-sulfophenyl group. 
や本川中流部で濃度が高い。また，冬に高く夏や秋に 低い。

\section{6 河川水中の界面活性剂の組成}

河川水中で LAS の占める割合は，水温が $25^{\circ} \mathrm{C}$ と高 い夏季には全陰イオン界面活性剂の $79.8 \pm 17.7 \%$ (平 均土標準偏差, $\mathrm{n}=8$ ), 水温 $^{\circ} 15^{\circ} \mathrm{C}$ と中程度の秋季に は81.9土6.1\% $(\mathrm{n}=10)$ であるが，水温が $5{ }^{\circ} \mathrm{C}$ と低い 冬季には $72.7 \pm 7.2 \%(n=13)$ となった。ぬた，実験 室的には最も生分解を受けやすい(1),2),4 サルフェート は夏季には全陰イオン界面活性剂中に10.3土6.5\% $(n=9)$, 秋季には7.9土6.4\% $(n=10)$ の割合を占め ているが，冬季には $23.2 \pm 6.0 \%(n=13)$ にもなる。 また, AOSは, 秋季には全陰イオン界面活性剤の2.6土

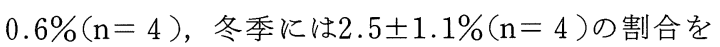
占めている。非イオン界面活性剂は, 秋季には全陰イ オン界面活性剤の $10.5 \pm 4.8 \%(\mathrm{n}=3)$, 冬季には $10.0 \pm 1.3 \%(n=4)$ の濃度で検出された。

\section{7 河川水中の LAS の同族体・異性体組成}

市販洗剂中の LAS はアルキル基の炭素数（以下 $\mathrm{Cn}$ と略す）が10～14と異なる同族体と各アルキル鎖長の LAS 毎にスルホフェニル基（以下 phと略す）のつく 位置の異なる数種の異性体とからなる。河川水中の LASの Cn と $2 \mathrm{ph}$ 異性体割合は Table 3 のように求 まった。地点による差が大きいが, 全地点の平均では,
$\mathrm{Cn}$ は夏季 $11.46 \pm 0.17(\mathrm{n}=11)$, 秋季 $11.52 \pm 0.12(\mathrm{n}=$ 13), 冬季 $11.56 \pm 0.12(\mathrm{n}=13)$ であり，また $2 \mathrm{ph}$ 異 性体割合は, 夏季 $11.5 \pm 5.3 \%(n=11)$, 秋季 $13.5 \pm$ $2.7 \%(n=13)$, 冬季 $15.3 \pm 3.8 \%(n=13)$ であった。

\section{4. 考察}

\section{1 界面活性剤の分析}

検水の前処理には，ディスポーザブル ODSミニカ ラム Bond Elut $\mathrm{C}_{18}$ を用いることにより, 種々の陰イ オン界面活性剤を水中から容易に濃縮分離することが できた。界面活性剂の水溶液からの分離には，一般に は溶媒抽出法が用いられている1),2)。しかし, 溶媒抽出 法は，本研究のように401 もの検水を処理する場合に は抽出・濃縮に多大の労力を必要とし，ぬたガラス器 具等からの污染も大きく，適切ではない。

全陰イオン界面活性剂は，検水をBond Elut $\mathrm{C}_{18}$ で 前処理した後メチレンブルー法で分析した。この值を 前処理なしの通常のメチレンブルー法で分析した值と 比較し, Fig.3に示した。河川水中にはメチレンブルー と錯体をつくる陰イオン界面活性剂以外の物質があ り, 全陰イオン界面活性剂濃度はMBAS 濃度の約 9 割であった。全陰イオン界面活性剂濃度は MBAS 濃 度と非常に良い相関を示すことから，前処理なしの通 常のメチレンブルー法で河川水中の全陰イオン界面活
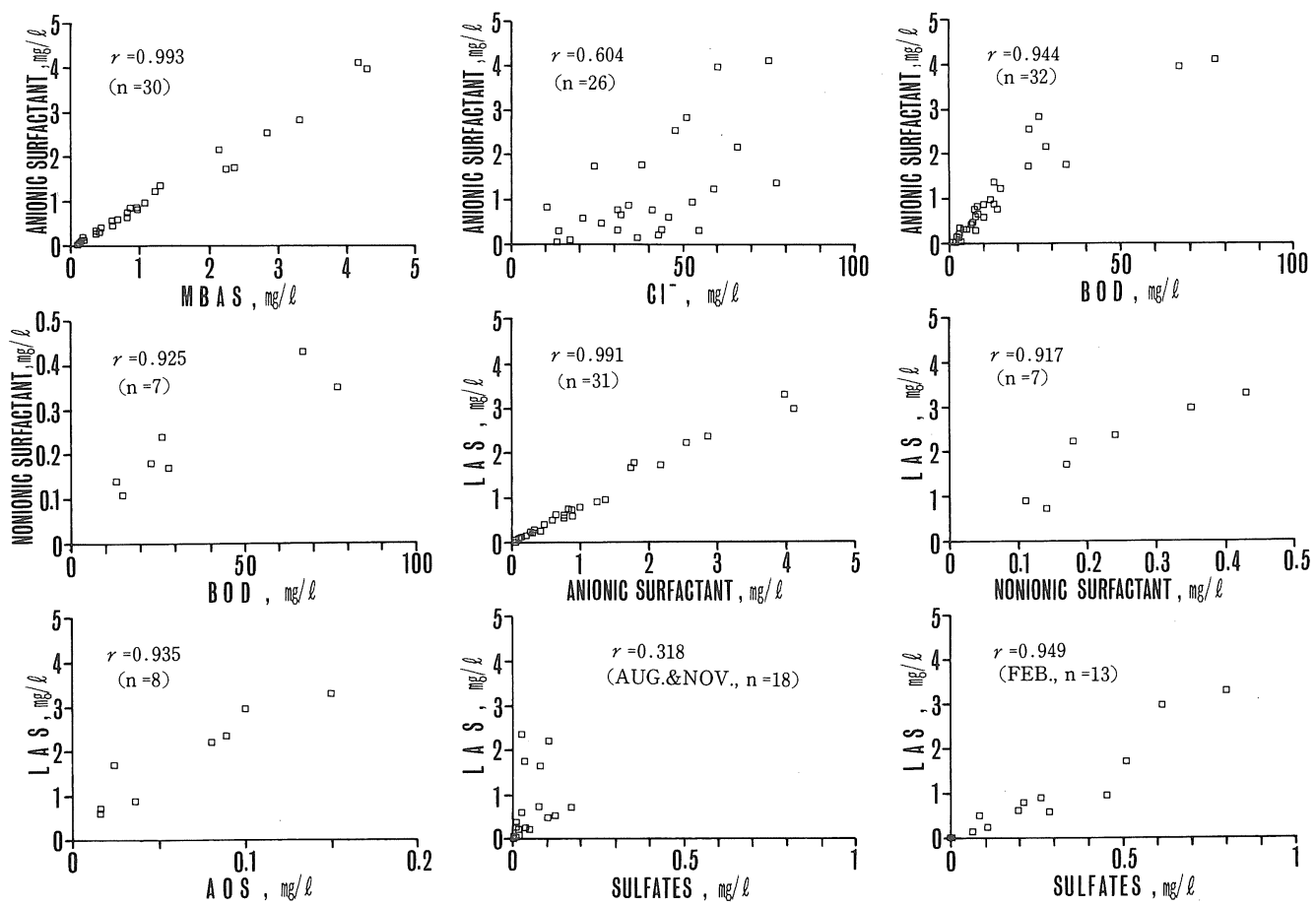

Fig.3 Relationship between selected water qualities. 
性剂濃度を良く把握できることが分かった。

\section{2 界面活性剂の河川中での挙動}

高・中・低水温で測定したデータを合わせて相関を みると, 全陰イオン界面活性剂及び非イオン界面活性 剂の濃度は, 塩化物イオン濃度とは相関が低いが, BOD 濃度とは良い相関を示す (Fig.3)。このことは, 全陰イオン界面活性剤及び非イオン界面活性剤は, 主 に生活排水中に含まれて排出されるが，塩化物イオン のように保存性を示すのではなく，河川を流下する過 程であるいは生活排水の処理過程で BOD と同様に除 去されることを示す。をた, 河川水質の BOD 污濁対策 は界面活性剤污染対策にも有効であることを意味して いる。

高・中・低水温で測定したデータを合わせて相関を みると, LAS 濃度は全陰イオン界面活性剂濃度と非常 に良い相関を示す。LAS は全陰イオン界面活性剂濃度 の約 7 〜 割を占めることから当然とも言える。また, $\mathrm{AOS}$ 之非イオン界面活性剂は中・低水温でのみ測定し ているが，LAS 濃度はAOS 及び非イオン界面活性剂 の濃度とも良い相関を示す (Fig.3)。このことは, 中。 低水温では, AOS と非イオン界面活性剤はLAS と同 様な挙動をとることを示している。

しかし, サルフェートの濃度は低水温では LAS 濃 度と良い相関を示すが，中・高水温ではまったく相関 がない(Fig.3)。このことは, 低水温ではサルフェー トはLAS と同様な挙動をするが, 中・高水温では LAS と異なった挙動をすることを示している。

河川水中の MBAS と非イオン界面活性剂濃度との 相関についてはすでにいくつかの報告がある。小島7 は，名古屋市内の河川水中の非イオン界面活性剂濃度 を分析し，MBAS/非イオン界面活性剤の平均值は9.5

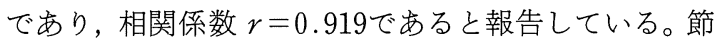
田 ${ }^{8)}$ は神奈川県内の河川水中の MBAS と非イオン 界面活性剂は

$$
\begin{gathered}
\mathrm{MBAS}=5.39 \times(\text { 非イオン界面活性剂 })^{0.904} \\
r=0.814(\mathrm{n}=60)
\end{gathered}
$$

の関係にあると報告している。これらの結果と著者ら のデータは执执むね一致している。

\section{3 河川水中での界面活性剤の組成とその季節変化}

三浦 ${ }^{9}$ は，陰イオン界面活性剂使用量のらち AOS と サルフェートの合計の比率が1983年には約 $50 \%$ に達し ていると推定している。つまり，市販の合成洗剤では 陰イオン界面活性剂の执よそ半分がLASである。し かし今回の調査によると, 河川水中では LAS の占め る割合はもっと多く, 全地点平均で夏季には $80 \%(n=$ $8)$, 秋季には $82 \%(n=10)$, 冬季には $73 \%(n=13)$ であった。滝田ら ${ }^{10)}$ 女, 多摩川水系の河川水中の陰イオ
ン界面活性剂濃度を分析しているが，彼らのデータか ら計算しても，1983年 7 月の検水では陰イオン界面活 性剂の組成はLAS $83 \pm 2 \%(n=4)$, サルフェート $17 \pm 2 \%(n=4), \operatorname{AOS} 1 \%(n=1)$ である。

この市販洗剂中と河川水中の界面活性剂組成の違い は，第一には河川中での吸着・沈殿・分解により，第 二には生活排水が下水道または合併処理浄化槽で処理 されることにより引き起こされると考壳られる。関口 ら ${ }^{11)}$ は，下水処理場に打ける陰イオン界面活性剂の除 去率を LAS 85\%，AOS 100\%，サルフェート 100\% と求めている。東京都内で1983年度に，排水が河川に 排出される区域に扣いて，下水道京たは合併処理浄化 槽によって生活排水が処理されている人口割合は $64 \%$ である ${ }^{12)}$ 。上記の除去率を用いて計算すると, 生活排水 の64\%が下水処理場等を経由して，36\%が直接に排出 される平均的な河川では, 製品中で $50 \%$ を占めた LAS はその河川水中では $56 \%$ となり，生活排水処理から上 記の違いを一部分説明できる。次に上記の違いへの河 川中での吸着・沈殿・分解の寄与を多摩川水系を一例 として考光る。(1)生活排水の $99 \%$ 以上が未処理で流入 する地点である和田橋と羽村堰でも，河川水中の全陰 イオン界面活性剂に占める LAS の割合は69 71\%も ある。(2)文献 ${ }^{13)}$ から計算すると, 昭和56年度に沶いて拝 島橋から田園調布堰までの間で BOD 発生負荷量の数 十\%が河川中での沈殿・分解により除去されているが， 陰イオン界面活性剂濃度と BOD 濃度とは良い相関を 示すことから, BOD と同様に陰イオン界面活性剂も河 川水中から除去されていると考えられる。石渡ら ${ }^{14)}$ 田園調布堰を通過する LAS の量は発生量の $7 \%$ \% ると計算している。(3)河川水を用いての生分解試 験 ${ }^{1), 2), 4)}$ からは, サルフェート及びAOS して容易に分解されることが分かっている。今回の調 査でも, $4.2 て ゙$ 述べたよらに, サルフェートは低水温で

Table 4 The t-test on the seasonal variation of the sulfates ratio(\%) to the anionic surfactant in the river waters.

\begin{tabular}{|l|c|c|c|}
\hline \multirow{2}{*}{ Group } & \multicolumn{2}{|c|}{ Difference at each station } & \multirow{2}{*}{$\mathrm{t}$} \\
\cline { 2 - 3 } & Mean & S. D. & \\
\hline Feb.-Nov. & 16.48 & 10.36 & $4.50^{* *}$ \\
Nov.-Aug. & -3.19 & 10.11 & -0.892 \\
Feb.-Aug. & 13.29 & 5.98 & $6.29^{* *}$ \\
\hline
\end{tabular}

Number of stations in each group : 8

The data at St.13 was excluded from the t-test due to presence of a sea water.

**Significant level : $\mathrm{p}<0.01$ 
はLAS と同様な挙動を示すが, 中・高水温では LAS と異なった挙動を示すことが分かっている。これらの ことから, 河川中での吸着・沈殿・分解によってサル フェート等が LAS に優先して水中から除去されるこ とが, 市販洗剂中と河川水中の界面活性剂組成に違い が生じる第一の原因であると考它らる。

河川水中でサルフェートが優先して生分解されてい るとすると，生分解は水温により大きな影響を受け る4) とから, 界面活性剤の組成は季節によって変化 すると推定できる。そこで，8月，11月と 2 月の測定 データのらち久測のある 4 地点执よび明らかに海水が 混合している 1 地点のデータを除いた 8 地点で, 全陰 イオン界面活性剤に占めるサルフェートの割合の季節 変化の有意差検定を行った。有意差検定は 8 月, 11 月 と 2 月の組成割合(\%)の差をとり, それらの平均がゼ 口とみなせるかどらかについて，対応のあるデータ群 間の差の検定を行った。Table 4 亿検定結果を示した が， 8 月と11月では有意差は認められなかったが，11 月と 2 月拈よび 8 月と 2 月では $1 \%$ 危険率で有意差が 認められた。つまり全陰イオン界面活性剤に占めるサ ルフェートの割合は 2 月と比べて 8 月と 11 月には明ら かに小さく, サルフェートは高・中水温の季節には低 水温の季節より容易に河川水中から微生物学的に除去 され, 界面活性剤の組成に季節変化が生じていること が分かった。

\subsection{LAS の同族体・異性体組成と河川中での挙動}

LAS 同族体のらちCnの多い同族体ほど，また異性 体のうちでは phがアルキル基の端につく異性体䚾 ぞ, 生分解を受けやすくまた底泥などに吸着されやす ( 13,2$), 15) \sim 20)$ 。市販洗剂中之河川水中の界面活性剂組成 の違いが，河川中での吸着・沈殿・分解と生活排水処 理により引き起こされたとすると, 河川水中で検出さ れる LAS の組成も市販洗剤中とは異なっているはず である。

LAS は主に洗䍜用粉末合成洗剂に配合されている が, 吉村 ${ }^{21)}$ のデータによると, 1983年に市販されていた 洗䍜用粉末合成洗剂 $(\mathrm{n}=5)$ 中の LAS の組成は, $\mathrm{Cn}=$ $11.62 \sim 11.78$ (平均11.67), $2 \mathrm{ph}$ 異性体割合= 15.5 28.0\%（平均 $18.3 \%$ ) であった。また著者らの 分析では, 1987年 1 月に市販されていた洗䍜用粉末合 成洗剂 $(\mathrm{n}=5)$ 中の LAS の組成は, モル平均で $\mathrm{Cn}=$ 11.73 12.89 (平均11.99), $2 \mathrm{ph}$ 異性体割合 $=$ $13.5 \sim 26.9 \%$ (平均 $18.7 \%$ )であった。東海 ${ }^{22}$ は, 下水 処理場への流入水 $(\mathrm{n}=12)$ 中の LAS はモル平均で $\mathrm{Cn}=11.47,2 \mathrm{ph}$ 異性体割合 $=19.8 \%$, 二次処理水 $(\mathrm{n}=11)$ では, $\mathrm{Cn}=11.21,2 \mathrm{ph}$ 異性体割合 $=3.6 \%$ と 報告している。また, Holmann ら ${ }^{23)}$ は, 下水処理場へ

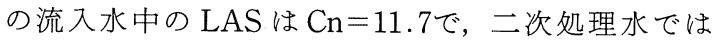
$\mathrm{Cn}=11.45$ と報告している。

これらのデータから, 市販洗剂中の LAS の平均組 成を $\mathrm{Cn}=11.7,2 \mathrm{ph}$ 異性体割合 $=19 \%$ 之推定した。

しかし河川水中では LAS の同族体・異性体組成は, 3.7で述べた值であり, この推定值とは異なった。吉村 $ら^{19)}$ 女, 多摩川田園調布堰近くの丸子橋の河川水中の LAS を分析しているが，1979年 6 月の検水では LAS の $\mathrm{Cn}=10.8$ と計算できる。 $2 \mathrm{ph}$ 異性体は検出されて いない。

そこで 4.3 と同様に, 生活排水の $64 \%$ が下水処理場等 を経由し，36\%が直接に排出される平均的な河川につ いて, 関口ら ${ }^{11)}$ の報告した下水処理場での LAS の除 去率と東海 ${ }^{22)}$ の報告した下水処理水中の LAS の組成 を用いて計算すると，その河川水中では LAS の $\mathrm{Cn}=$ $11.60,2 \mathrm{ph}$ 異性体割合 $=15.8 \%$ となり，上記の違い を生活排水処理により一部分説明できる。をた，生活 排水の $99 \%$ 以上が未処理で流入する地点である多摩川 和田橋では $\mathrm{Cn}=11.49 \sim 11.73,2 \mathrm{ph}$ 異性体割合= $13.8 \sim 15.2 \%$, 羽村堰では $\mathrm{Cn}=11.62 \sim 11.68,2 \mathrm{ph}$ 異性体割合 $=13.1$ 19.6\%であり，いずれの地点の値 も製品中の LAS 組成の推定值よりも小さい場合が多 い。したがって，上記の違いは，LAS の同族体・異性 体のらちCnの多い同族体及び $2 \mathrm{ph}$ 異性体が, 他の同 族体・異性体に優先して河川水中から吸着・沈殿・分 解により除去されることも原因となっていると推定で きる。

生分解は水温により大きな影響を受ける4)ことか ら, LAS が河川中で生分解を受けているかどらかは, LAS の組成が季節によって変化するかどらかによっ て検証できる。そこで Table 4 と同様の手法で, LAS

Table 5 The $\mathrm{t}$-test on the seasonal variation of LAS composition in the river waters.

\begin{tabular}{|l|l|l|l|l|}
\hline \multirow{2}{*}{ Item } & \multirow{2}{*}{ Group } & \multicolumn{2}{|c|}{ Difference at each station } & \multirow{2}{*}{$\mathrm{t}$} \\
\cline { 3 - 4 } & & Mean & S.D. & \\
\hline Carbon & Feb.-Nov. & 0.0770 & 0.0826 & $2.95^{*}$ \\
number & Nov.-Aug. & 0.0600 & 0.0660 & $2.87^{*}$ \\
(Cn) & Feb.-Aug. & 0.137 & 0.131 & $3.31^{* *}$ \\
\hline 2 ph, & Feb.-Nov. & 2.65 & 1.92 & $4.36^{* *}$ \\
mol\% & Nov.-Aug. & 1.44 & 4.17 & 1.09 \\
& Feb.-Aug. & 4.09 & 3.99 & $3.24^{*}$ \\
\hline
\end{tabular}

Number of stations in each group : 10

The data at St.13 was excluded from the t-test due to presence of a sea water.

*Significant level : $p<0.05$

**Significant level: $p<0.01$ 
の $\mathrm{Cn}$ と $2 \mathrm{ph}$ 異性体割合の季節変化の有意差検定を 行った (Table 5)。その結果, LASのCnは 8 月, 11 月，2月と水温が低くなるにつれて多くなり，また， $2 \mathrm{ph}$ 異性体割合は水温が低い 2 月には多くなること が分かった。つまり，LASの組成は季節によって変化 し，水温が高・中程度の季節には LAS の同族体・異性 体のらち Cnの多い同族体と $2 \mathrm{ph}$ 異性体は優先して 微生物により分解されていることが分かった。モデル 河川での室内実験で，河川を流下する過程で LAS の 濃度が低下するとともにLAS の組成が変化すると報 告されている(16)が，そのような組成変化が実際の河川 中でも起こっていることが今回の現場調査により明ら かになった。

このように，界面活性剂の組成执よび LASの同族 体・異性体組成は，市販の製品中と河川水中とではや や異なり，また季節によってもやや異なるが，これは 室内実験データ等と合わせて考察すると, 河川中での 吸着・沈殿・分解及び生活排水処理によりある特定の 成分が優先して除去されるためであることが分かっ た。

AOS と非イオン界面活性剂の濃度は秼)クルト本 社中央研究所付属分析センターが分析した。

\section{（原稿受理 昭和62年12月22日）}

\section{文献}

1 ) Arthur D. Little, Inc. (1981) 界面活性剂の科学 一人体抒 よび環境への作用と安全性——(黒岩幸雄監訳), フレグランス ジャーナル社, 東京.

2 ) 社)日本水質污濁研究協会(1986)界面活性剤の水環境に及ぼ す影響等に関する調査報告書, 東京.

3 ) M. Kikuchi and M. Wakabayashi (1984) Lethal response of some surfactants to medaka Oryzias latipes with relation to chemical structure, Bull. Japan. Soc. Sci. Fish. 50, 1235-1240.

4 ) 菊地幹夫 (1985) 界面活性剂の河川水中での生分解, 日水誌, 51, $1859-1864$.

5 ) 財)日本規格協会 (1981) 日本工業規格「工場排水試験方法」JIS K0102-1981，東京。

6) M. Kikuchi, A. Tokai and T. Yoshida (1986) Determination of trace levels of linear alkylbenzenesulfonates in the marine environment by high-performance liquid chromatography. Water Research, 20, 643-650.

7 ) 小島節子(1982)市内河川水中の非イオン界面活性剤の定量, 名古屋市公害研究所報, 12, 83-87.

8 ）節田節子, 森康明, 長谷川一夫, 内藤昭治 (1982)神奈川県内 の河川水中のポリオキシェチレン系非イオン界面活性剤の分 布, 水質污濁研究, $5,1-7$.

9 ) 三浦千明 (1987)合成洗剤と環境一環境測定データからの考 察一, 水質污濁研究, 10, 315-321.

10）滝田八広, 大場健吉 (1985)多摩川河川水の陰イオン系界面活 性剂の微量分析, 水質污濁研究, 8, 752-754.

11）関口一, 三浦千明, 八木良一, 大場健吉 (1975)都市下水処 理によるアニオン界面活性剂除去に関する検討, 油化学, 24 , 311-313.

12) 東京都環境保全局(1985)污濁総量管理システムによる負荷 量集計結果(拔粋) 一一昭和58年度一, $\mathrm{pp} 61-88$.

13）東京都(1983)東京地域公害防止計画, $\mathrm{pp} 90$-92.

14）石渡良志, 高田秀重, 斉藤裕政, 尹順子(1986)東京湾周辺環 境における有機污染物質の挙動：多環芳香族炭化水素および アルキルベンゼン, Res. Org. Geochem., 5, 51-55.

15) H. Hon-nami and T. Hanya (1980) Difference in the composition of linear alkylbenzene sulfonate homologues in river sediment and river water. Jap. J. Limnol., 41, 1-4.

16）大場健吉, 杉山豊樹, 三浦千明, 森崎やよい(1977)生分解過 程に拈けるLAS の魚毒性, 日水誌, 43，1001-1008.

17）吉村孝一, 中栄篤男(1982)活性污泥による直鎖アルキルベン ゼンスルホン酸ナトリウム(LAS)の生分解性に関する研究 (I) - LAS の吸着機構について——, 水質污濁研究, 5, 19-25.

18）吉村孝一, 中栄篤男(1982)活性污泥による直鎖アルキルベン ゼンスルホン酸ナトリウム(LAS)の生分解性に関する研究 (II) - LAS の吸着と生分解——, 水質污濁研究, 5, 63-72.

19）吉村孝一，林克己，川瀨次朗，辻和郎 (1984)河川中に拈ける 陰イオン界面活性剂の存在, 陸水学雑誌, 45, 51-60.

20）山本修一, 石渡良志, 本波裕美(1981)水環境に扣ける堆積高 分子有機物(Kerogen) と ABS との相互作用, 水質污濁研究,

4, 65-72.

21) 吉村孝一(1983)私信.

22) 東海明宏 (1985) 東京水産大学大学院修士論文「東京湾に扣け る数種の環境污染物質の研究」.

23) W.F. Holman and K.J. Macek (1980) An aquatic safety assessment of linear alkylbenzene sulfonate (LAS): Chronic effects on fathead minnows. Trans. Am. Fish. Soc., 109, 122-131. 


\section{東京都内河川水中の界面活性剤の濃度分布と挙動}

菊地 幹夫* 渡辺のぶ子** 小河原道正 ${ }^{* *}$ 紺野 良子** 桜井 博** 中島 秀和**

* 東京都環境科学研究所 $* *$ 東京都環境保全局

〈水質污濁研究 Vol.11 No.4 （1988）pp.248 256〉

河川水中に存在する界面活性剂の種類及びその挙動を明らかにすることを主目的にして, 東京都内 10 河川13 地点を調査した。界面活性剤の濃度は, 支川で高く, 本川で低く, また, 夏・秋に低く, 冬に高かった。全陰 イオン界面活性剤のうち, LAS は73 82\%で, AOS は $2 \%$ で, サルフェート型陰イオン界面活性剂は 8 23\% であった。非イオン界面活性剂は全陰イオン界面活性剂の約 $10 \%$ の濃度で検出された。界面活性剂の濃度と生 物化学的酸素要求量 (BOD)濃度とは良い相関を示すことから, 界面活性剂は河川を流下する過程であるいは生 活排水処理により，BOD と同程度に除去されることが分かった。界面活性剂の組成は，市販の製品中と河川水 中とではやや異なり，また季節によってもやや異なったことから，河川中での吸着・沈殿・分解抒よび生活排 水処理により，界面活性剤のある特定の成分は他の成分に優先して除去されることが分かった。

\section{フィリピンにおける地下水水質について}

大久保俊治* 大塚佳代子** 美和 或男*** 野手 草生**

* 日本上下水道設計秼横浜事務所 $* *$ 日本上下水道設計秼技術部 $* * *$ 日本上下水道設計秼海外事 業部

〈水質污濁研究 Vol.11 No.4 （1988）pp.257 261〉

フィリピンに打ける水道水源は主に地下水(涌水を含む)に頼っているのが現状である。しかしながら,フィ リピンの水道事業やその水質に関する報告は汪とんどない。

本論文ではフィリピンの水道事業の現状を紹介する一方, フィリピンの各プロビンス (provinces) ごとに水 道事業拉よび水質の特徵を把握した。また, フィリピンの地下水水質はアルカリ度や Mnイオン等の溶存物質 が多い傾向が見られた。 